\title{
A reescrita do Novo Testamento e a crítica social em "A morte de Jesus", de Eça de Queirós
}

\section{The rewriting of the New Testament and social criticism in Eça de Queirós' “A morte de Jesus” [Jesus' Death]}

\author{
Jean Carlos Carniel ${ }^{*}$ \\ jc.carniel@hotmail.com \\ Universidade Estadual Paulista (UNESP) \\ Luciene Marie Pavanelo* \\ pavanelo@ibilce.unesp.br \\ Universidade Estadual Paulista (UNESP)
}

RESUMO: Objetiva-se, com este trabalho, analisar a reescrita do Novo Testamento e a crítica social no conto "A morte de Jesus", de Eça de Queirós, pautando-se sobretudo em críticos como Saraiva (1982), Bueno (2000) e Nery (2005). O autor de Prosas Bárbaras aborda uma visão conhecida do texto religioso, porém, sob uma perspectiva de uma personagem ficcional, que não está na Bíblia. Entretanto, notase que o texto de Eça apresenta uma visão crítica da personagem Jesus, indo além da versão canônica bíblica. Além do mais, a sociedade do tempo de Cristo é retratada de forma semelhante à do século XIX, destacando-se a hipocrisia e o materialismo presentes nessas duas sociedades, $O$ que nos sugere que, ao reconstruir o passado para relatar uma história conhecida do público leitor, Eça também faz uma reflexão sobre o Oitocentos.

PALAVRAS-CHAVE: Eça de Queirós. Prosas Bárbaras. Narrativa bíblica.

ABSTRACT: This paper aims to analyze the rewriting of the New Testament and the social criticism in the short story "A morte de Jesus" [Jesus' Death] by Eça de Queirós, based mainly on critics such as Saraiva (1982), Bueno (2000) and Nery (2005). The author of Prosas Bárbaras approaches a well-known view of the religious text from the perspective of a fictional character not found in the Bible. Nevertheless, we note that this text presents a critical vision of the character Jesus, going beyond the canonical biblical version. Moreover, the society of the time of Christ is portrayed in a similar way to the one of the nineteenth century, highlighting the hypocrisy and the materialism present in these two societies. This suggests that as Eça reconstructs the past to tell a story known by the readership, he reflects about the nineteenth century.

KEYWORDS: Eça de Queirós. Prosas Bárbaras. Biblical narrative.

\footnotetext{
* Mestrando em Letras pela Universidade Estadual Paulista (UNESP). Bolsista da Fundação de Amparo à Pesquisa do Estado de São Paulo (FAPESP), processo n $2016 / 25008-2$.

${ }_{*}^{*}$ Doutora em Estudos Comparados de Literaturas de Língua Portuguesa pela Universidade de São Paulo (USP). Professora da Universidade Estadual Paulista (UNESP).
} 
A narrativa "A morte de Jesus" foi publicada por Eça de Queirós entre abril e julho de 1870, no jornal $A$ revolução de Setembro e foi, postumamente, compilada por Luís de Magalhães no volume Prosas Bárbaras (1903). Esse conto será analisado com o objetivo de verificar como o autor trabalha, nele, a reconstrução da narrativa bíblica e a crítica social.

Esse texto é considerado inacabado pela crítica queirosiana, porque apesar do título, não se chega a narrar a morte de Jesus. Entretanto, para Marie-Hélène Piwnik (2009, p. 18), esse conto apresenta uma conclusão concebível ao leitor e pode ser lido como uma narrativa fechada. A estudiosa também aponta que "é possível que 'A morte de Jesus' tivesse a ambição de ser um romance cujo inspirador bem podia ter sido [Ernest] Renan" (PIWNIK, 2009, p. 18).

Jaime Batalha Reis (1951, p. 50), na introdução de Prosas Bárbaras, afirma que Eça começou a escrever esse relato após a sua viagem à Palestina e que ele escreveu, além dos nove capítulos que foram publicados, alguns outros que ou foram destruídos ou se perderam, corroborando a ideia de que essa narrativa poderia vir a ser um romance. O crítico também relata que Eça, naquela época, era não apenas leitor de Flaubert, mas "lia também a Vida de Jesus, o São Paulo, de Ernesto Renan, e As memórias de Judas, de Petruccelli della Gattina" (REIS, 1951, p. 50). Com essa afirmação, observa-se que Eça era leitor de narrativas de temática bíblica, escritas por autores estrangeiros.

"A morte de Jesus" é introduzida por uma nota supostamente escrita no Mediterranean Hotel, em Jerusalém, datada de 1 de dezembro de 1869 (data relativamente próxima do momento da publicação dessa narrativa):

Por estranhos acasos encontrei este velho manuscrito copiado, num latim bárbaro, do antigo papiro primitivo. Não o traduzo textualmente: seria incompreensível, irritaria os nossos hábitos críticos, psicológicos! Transporto para a linguagem moderna complexa, dúctil, sábia, o estreito dizer antigo (QUEIRÓS, 2009, p. 117).

Nessa passagem, há a tópica do manuscrito encontrado, que é bastante utilizada nos romances históricos oitocentistas. Assim, o autor finge que está traduzindo um texto real, supostamente escrito na época de Cristo e posteriormente copiado, para convencer o leitor de que se trata de uma narrativa verdadeira.

Há ainda, nesta nota, a afirmação de que o documento põe "em relevo muitos estados de espírito, muitas situações civis de uma pessoa excepcional, que tem 
notavelmente merecido nestes últimos tempos a atenção da história e da crítica" (QUEIRÓS, 2009, p. 118). A saber, essa figura destacada é Jesus Cristo, uma personagem recorrente nas obras queirosianas, tal como pode ser observado no romance $A$ relíquia, além de outros contos como "O suave milagre", "Outro amável milagre" e "Um milagre"1.

Como já afirmado, a narrativa se divide em nove capítulos. Logo nas primeiras linhas temos a apresentação do narrador, portanto aquele que, supostamente, teria sido o verdadeiro autor do manuscrito: "o meu nome é Eliziel, e fui capitão da polícia do Templo: estou velho e inclinado para a sepultura; e antes de me deitarem para a eternidade [...] quero contar o que sei e o que vi dum homem excelente" (QUEIRÓS, 2009, p. 118). Com isso, o personagem Jesus é apresentado ao leitor por meio do olhar crítico e subjetivo desse narrador.

Maria de Fátima Marinho afirma que Eça apresenta "alguma novidade ao escrever o texto em primeira pessoa, fato bastante incomum no romance histórico tradicional" (MARINHO, 2005, p. 170). Além disso, para a estudiosa,

ao atribuir a narração a um capitão da polícia do Templo que evoca o seu testemunho sobre um homem que apelida de excelente, Eça aproxima-se, sem disso poder ter plena consciência, de romances da pós-modernidade, ao relativizar o passado que se transforma no produto de uma focalização interna, sempre redutora e subjetiva (MARINHO, 2005, p. 170; grifo da autora).

Esse recurso seria, dessa forma, uma característica que afastaria essa narrativa dos tradicionais romances históricos, apesar da utilização da tópica do manuscrito encontrado, típica desse tipo de romance. Além do mais, a utilização de um narrador em primeira pessoa interessa-nos por causa do caráter crítico e questionador, pois Eliziel é um sujeito que se indaga sobre os acontecimentos do tempo dele. Assim, desde o início da narrativa, sabemos que o narrador decidiu compor as suas memórias para trazer o seu olhar sobre a vida de Jesus.

Ao analisar o personagem Eliziel, Aparecida de Fátima Bueno afirma que, por ser um policial do Templo, ele "poderia representar [...] o guardião de uma série de valores que estão associados à ordem do sagrado, isto é, a códigos éticos e morais elevados [...]" (BUENO, 2000, p. 148). Isso pode ser observado pelo caráter crítico de Eliziel, uma vez que ele repudia as práticas mercantis realizadas no Templo. Por

\footnotetext{
${ }^{1}$ Para uma análise de Cristo na obra de Eça de Queirós, ver Bueno (2000). 
ser um guardião, o personagem conheceu Jesus na passagem bíblica conhecida como a expulsão dos mercadores no Templo. Já nesse primeiro contato, há a sugestão de que ele simpatiza com Jesus, pelo fato de Cristo também combater o comércio naquele lugar:

Mas o que na vida do Templo me indignava superiormente era vê-lo tornado um lugar de comércio, de venda e de troca de moeda. $E$ foi por este ódio aos mercadores do Templo, que além disso me tornavam a polícia difícil e fatigante, que eu conheci o homem inefável, por quem os meus olhos ainda se humedecem (QUEIRÓS, 2009, p. 121).

Depois disso, Eliziel passa a se interessar por Jesus, porém a curiosidade dele se dá de modo crítico e questionador:

Mas o que era aquele homem? Era um simples visionário? Era um contemplador, cheio da melancolia que dão as espessuras de Galileia, e tomado dum desdém divino? Era um espírito cheio de sabedoria? Era um continuador de Juda Gaulonite? Vinha ele pregar contra o imposto e contra o dízimo? Era ele hostil a César, e cheio da tradição dos Macabeus? Era um simples? Era um crente? Era um especulador frio das esperanças messiânicas? Vinha ele atacar o espírito do Templo? (QUEIRÓS, 2009, p. 132).

Nesses questionamentos, Eliziel não descarta a possibilidade de Jesus ser um visionário ou um charlatão. Ademais, as características abaixo, retiradas da passagem da expulsão dos mercadores do Templo e atribuídas por Eliziel, aproximam Jesus do plano terreno, sobretudo, com características humanas:

Era alto, magro, fraco: tinha os cabelos louros, pendentes, separados ao meio, cabelos de homem da Galileia; mesmo, percebi logo, pelo acento e pela pronúncia, que era galileu; naquele momento o seu rosto era irritado e severo; tinha o gesto largo ao modo dos que pregam nas sinagogas, tinha as feições inflamadas, os olhos cheios duma luz indignada; a sua estatura erguida pela cólera, enobrecida pela justiça das suas palavras, cheia do seu pensamento, fazia parecer mais que um homem (QUEIRÓS, 2009, p. 122).

Apesar de o narrador sugerir que a expressão colérica de Jesus o fazia parecer mais que um homem, acreditamos que essa superioridade possa estar relacionada ao fato de Eliziel acreditar que Jesus poderia ser um líder, deste modo, ele estaria acima dos demais. Além disso, as reflexões de Antonio Augusto Nery podem nos ser úteis para reforçar tal pensamento. Nery $(2005$, p. 86$)$ aponta que Eliziel não está interessado por Jesus por motivos cristãos, pois, para o guardião do 
Templo, o interesse se dá pelo fato de o Nazareno ser um possível líder revolucionário. Nery também assinala que, para o narrador, Jesus não seria uma espécie de ser miraculoso, tal como seria a visão apresentada na Bíblia. O estudioso analisa a fundo o personagem Eliziel e diz que ele poderia ser um zelote, isto é, de um grupo de judeus que se opunham à invasão romana em Israel, cujo objetivo era a independência de sua nação. Essas reflexões nos ajudam a compreender melhor esse personagem, pois justifica o desejo de Eliziel por melhores condições para a sua pátria.

António José Saraiva aponta que Eça se detém nas qualidades humanas e morais de Jesus: "considerado como homem, despido da sua qualidade divina, o Cristo histórico tem já nesta época, uma extrema sedução para Eça. Esta sedução vem de certas qualidades humanas, morais (não divinas nem transcendentes)" (SARAIVA, 1982, p. 84). Para o crítico português, esse Cristo é "o primeiro grande apóstolo da fraternidade entre os homens, da exaltação dos humildes" (SARAIVA, 1982 , p. 85), e isso pode ser verificado nas passagens em que Jesus prega o desapego material: "- Vendei o que possuís, dizia ele, dai o dinheiro em esmolas!" (QUEIRÓS, 2009, p. 135). Além disso, para o estudioso (1982, p. 115), essa visão de Jesus como um ser comum coincide com a visão de Ernest Renan. Deste modo, de acordo com Saraiva, o Nazareno idealizado por esse autor seria "doce, caridoso, precursor de um socialismo todo moral e afetivo, vítima das classes estabelecidas" (SARAIVA, 1982, p. 115).

Ainda em se tratando da representação de Cristo, para Bueno, o que se vê nesse conto é a mesma visão considerada canônica sobre a vida de Jesus: "mesmo Eliziel questionando de forma crítica o comportamento do Rabi da Galileia, pelo fato de ele não querer liderar uma revolução, [...] as ideias presentes nesse conto mantêm a filiação ao texto bíblico" (BUENO, 2000, 152-153).

A pesquisadora, ao analisar a figura de Cristo na obra de Eça de Queirós, chega à conclusão de que

o que se depreende da leitura dos diversos Cristos de Eça é que ele parece realmente separar as imagens de Jesus Cristo da Igreja Católica - e salvaguardar a primeira - pelo menos quando não pretende demolir a Instituição religiosa, como parece ocorrer em $A$ relíquia. Ou seja, que reservaria, sempre que possível, uma imagem positiva para o herói do Novo Testamento e a sua mensagem, mas cobrando dele o empenho revolucionário, como ocorre em "A morte de Jesus" [...] (BUENO, 2000, p. 182). 
Deste modo, a afirmação de Bueno parece se encaixar na análise que estamos propondo desse conto, pois podemos observar que Eça, nessa narrativa, apresenta uma visão positiva de Jesus, embora seja observado o tom crítico de Eliziel em esperar de Jesus o início de uma revolução. Podemos concluir que Eça aborda uma versão conhecida do texto bíblico, porém sob uma perspectiva de um personagem ficcional, que não estaria na Bíblia. A visão canônica parece se justificar com as palavras do autor na nota que precede o conto, ao dizer que o seu relato serve como um "documento, que não encerra coisas novas" (QUEIRÓS, 2009, p. 118), ou seja, não traz um olhar diferente das coisas já conhecidas e canônicas. Contudo, Eça traz uma versão canônica sob a perspectiva de um personagem ficcional crítico. Bueno destaca que

é justamente nessa crítica de Eliziel, na cobrança que ele faz a Jesus por ele não liderar uma revolução que expulsasse os romanos e unificasse o povo de acordo com leis consideradas por ele como mais justas, é precisamente através dessas críticas que podemos ver as posturas do escritor português (BUENO, 2000, p. 153).

Com base nesse argumento de Bueno, poderíamos dizer que o texto de Eça vai além do olhar canônico, por apresentar uma visão crítica da figura de Jesus.

Nery afirma que essa narrativa mostra a "exploração da incompatibilidade que Jesus demonstrava frente aos problemas terrenos, uma tensão existente entre a luta material/política e a luta pelo plano divino" (NERY, 2005, p. 99). Essa oposição entre o plano material e o divino se dá pelo fato de Jesus não resolver os problemas terrenos, já que, tal como ele afirma, o seu reino não seria deste mundo; isto é, a sua única preocupação seria salvar as almas das pessoas, tendo em vista, portanto, a vida após a morte.

Essa preocupação fica evidente no final da narrativa. Eliziel, ao se encontrar com Jesus, espera obter informações sobre qual seria o propósito dele. O guardião do Templo esperava que o Cristo desse início a uma revolução. Contudo, Jesus é contrário às intenções do narrador-personagem:

- Eu [...] digo que és um homem mandado providencialmente, num tempo humilhado e vil, para erguer as almas, desmascarar as hipocrisias, vingar a pátria! [...]

- Homem, em que espírito estás? Eu vim a salvar as almas, e não a perdê-las.

- E é perdê-las torna-las justas? É perdê-las, o combater este sacerdócio rico e indiferente, este culto ensanguentado e hipócrita? É 
perdê-las o quebrar-lhes este destino que as traz escravas, sempre choradas e sempre perdidas, e agora sob o arbítrio dos favoritos imbecis de Tibério?

- Essas coisas pequenas não me pertencem: são do mundo.

- [...] Mas então para que vieste a Jerusalém? Para que pregas no

Templo? Se tu não és uma iniciativa revolucionária, o que és então?

[...] De que nos servem essas parábolas, essas ironias, essas respostas excelentes, se elas não vão ferir a riqueza do saduceu, a hipocrisia do escriba, a vexação do romano? Queres abster-te da ação? (QUEIRÓS, 2009, p. 161-162).

Nesse diálogo, Eliziel reflete sobre a sua época, chegando a reconhecer que o povo precisa de um líder que vingue a pátria e combata a hipocrisia; entretanto, ele tem as suas expectativas quebradas, pois Jesus renuncia à força revolucionária e, por isso, não teria o poder de agir ativamente sobre o povo. O narradorpersonagem elenca uma série de motivos para que Jesus comece uma revolução. No entanto, o Cristo se mostra incapaz de resolver os problemas terrenos, chegando a ser enfático de que sua preocupação diz respeito ao plano espiritual: “- Vai-te: o meu reino não é deste mundo" (QUEIRÓS, 2009, p. 165).

Ainda para Nery, a "não preocupação de Jesus com regras, leis, doutrinas e instituições é sempre ressaltada. A intenção de criticar a Igreja Católica que dava muito valor a ritualismos, dogmas e doutrina é clara" (NERY, 2005, p. 101). Essa crítica seria visível, por exemplo, na condenação ao mau uso do Templo, já que ele se torna uma espécie de mercado, tal como narra Eliziel:

[...] desgostava-me, e muitas vezes o disse, que o serviço do culto autorizasse factos indignos da santidade da Lei, e da consagração do lugar, porque, no recinto do Templo, vinham estabelecer-se toda a sorte de vendedores e de bazares: vinham ali vender os animais para os sacrifícios, os estofos, os véus, as faixas de Tiro, trocava-se a moeda, negociava-se o azeite; e como o Templo era o centro vital de Jerusalém, havia ali toda a semelhança de uma feira: pregões, fardos, arcas; e mais parecia o mercado pagão de Cesareia, do que o interior da casa de Deus (QUEIRÓS, 2009, p. 120).

$\mathrm{Na}$ passagem acima, fica explícito o desagrado do narrador por aqueles que desrespeitam o Templo. Além do mais, esse local, segundo essa descrição, parece ter as suas funções primárias - a celebração religiosa - rebaixadas, já que se torna uma espécie de mercado.

Além disso, Bueno destaca que já é possível observar o caráter crítico de Eça, presente desde o início da carreira: 
já o encontramos, porém, adotando uma postura bastante crítica diante de Jesus Cristo. O narrador desse conto, se ainda não alcançou a ironia e o estilo mordaz que caracterizará o autor de $A$ cidade $e$ as serras na maturidade, esse narrador já apresenta, entretanto, uma crítica a Jesus que é precursora do estilo combativo que Eça adotará mais tarde. Podemos pensar isto porque Eliziel espera e cobra do Cristo o que Eça e a sua Geração certamente cobravam de si próprios: "és um homem mandado providencialmente, num tempo humilhado e vil, para erguer as almas, desmascarar as hipocrisias, vingar a pátria [QUEIRÓs, 2009, p. 161]" (BUENO, 2000, p. 153).

Concordamos com Bueno no fato de os questionamentos do personagem Eliziel relacionarem-se não apenas com o tempo de Cristo, mas também com o século XIX. Poderíamos estender a crítica não apenas à figura de Cristo, mas à sociedade oitocentista, já que a sociedade do tempo de Cristo é representada de modo semelhante à do século XIX, o que nos leva a concluir que Eça reconstrói o passado para relatar uma história conhecida do público leitor - uma vez que no século XIX praticamente todos conheciam as passagens bíblicas - e também fazer uma reflexão sobre o Oitocentos.

Saraiva se atenta ao caráter crítico de Eça. Para o estudioso português (1982, p. 13), é possível observar, em grande parte da obra queirosiana, meditações e comentários sobre os acontecimentos de seu tempo. Para ele, o escritor é "o representante e o intérprete de certo número de ideias coletivas, [...] em determinada época num determinado meio" (SARAIVA, 1982, p. 61). Apesar de o pesquisador apontar essa característica nas obras posteriores de Eça, pensamos que tal atributo também está presente na produção inicial do autor.

O posicionamento de Saraiva é semelhante ao de Djacir Menezes (1962), que vê a literatura como uma experiência social que "denuncia o estado de desenvolvimento da consciência coletiva e dos grupos, das suas lutas por objetivos socialmente configurados em condições de existência definidas" (MENEZES, 1962, p. 23). Além disso, Menezes também observa a postura crítica do escritor português, ao afirmar que

sua obra vale antes de tudo pelo conteúdo de crítica social: crítica à educação, crítica ao clericalismo, crítica à política, à organização da família, ao servilismo literário, à dissolução dos costumes políticos, à pasmaceira geral da pátria (MENEZES, 1962, p. 38). 
Com essa visão, percebemos que a literatura dialoga com o contexto histórico de produção, além de ela revelar o pensamento coletivo de determinados grupos. $O$ crítico brasileiro ainda afirma que "as criações literárias são produtos fabricados com o material já existente; e o artista, que o modela, é também um indivíduo que pertence a uma sociedade determinada" (MENEZES, 1962, p. 24). Vê-se, portanto, que a literatura está inserida dentro de um mundo determinado. O estudioso, dessa forma, pretende uma análise da literatura que esteja intrinsicamente ligada à análise e observação da sociedade.

Consideramos válidas tais observações, pois ponderamos que a obra de Eça de Queirós dialoga fortemente com o século XIX, isto é, com o momento de produção. Além do mais, geralmente, a crítica social está associada aos romances realistas escritos por Eça, tais como O crime do padre Amaro, O primo Basílio e Os Maias, por exemplo; entretanto, essa crítica também pode ser encontrada nas primeiras produções de Eça.

Na narrativa "A morte de Jesus", Eça faz uso da reconstrução de uma narrativa bíblica para lançar uma crítica à sociedade dos Oitocentos. Deste modo, a crítica social é observada nos questionamentos que Eliziel faz a Jesus, isto é, ele espera que ele seja um líder revolucionário e comece uma revolução. Além do mais, a crítica está no fato de que a sociedade do século XIX é também hipócrita e materialista; portanto, poderíamos fazer um paralelo com o desejo de mudança na geração de Eça.

Ademais, Bueno destaca que

É esse Cristo que vem para resgatar o pobre e o oprimido, condenar os ricos, aniquilar o sacerdócio corrompido, expulsar o romano, que vem, portanto, para promover uma verdadeira revolução nessa sociedade, é esse Cristo revolucionário que se quer no conto "A morte de Jesus". (BUENO, 2000, p. 187).

Deste modo, com base nessa afirmação, acentua-se que seria esperado que Jesus fosse capaz de resolver os problemas terrenos, a fim de combater as desigualdades sociais, além de dar a liberdade (concretizada na expulsão dos romanos) a seu povo.

Como já mencionado, Eliziel se questiona sobre o comportamento de Jesus; contudo, ele também busca diferentes opiniões, chegando a perguntar para diversas pessoas quem seria aquele homem. Ao longo de suas indagações, observa-se que 
ora há um olhar positivo, como o de Gamaliel - "penso que é um justo" (QUEIRÓS, 2009 , p. 125) -, ora negativo, como o de Josué: "[Jesus] não respeitava nem os ricos, nem os sacerdotes, nem os fariseus; [...] queria distribuir as riquezas pelos pobres; [...] era um vagabundo dos montes da Galileia, sem autoridade entre os doutos e entre os ricos" (QUEIRÓS, 2009, p. 132).

Temos, assim, dois olhares sobre esse personagem bíblico. Se, por um lado, há quem ache Jesus um justo, por outro, ele é descrito de modo negativo, chegando a ser comparado como um vagabundo que não era respeitado pelas autoridades. Tal como resume Eliziel, em seu encontro com Jesus: "- Uns, Mestre, dizem que és Elias, ou o Baptista ressuscitado, outros que és o Messias; os fariseus pensam que és um blasfemador ambicioso, ou um simples sincero, a maior parte ignora-te: esta é a verdade" (QUEIRÓS, 2009, p. 161).

Contudo, mesmo com comentários diversos sobre Jesus, Eliziel acredita no caráter revolucionário do Rabi, ainda que sua crença sobre um líder messiânico seja questionada, já que ele afirma que "não direi o que penso da intenção profética e da crença messiânica. Só direi que os profetas [...] eram bons; eram uma voz coletiva, a esperança, a consolação e o alívio" (QUEIRÓS, 2009, p. 122-123, grifos nossos). Com isso, Eliziel se isenta de emitir a opinião sobre a crença a um líder messiânico, mas destaca que esses possíveis líderes eram vistos de bom grado pela população.

Com essa posição, há a sugestão de que Jesus poderia trazer a consolação e o alívio, além de representar a voz coletiva da massa e os ideais do povo. O líder messiânico, portanto, daria voz para as camadas subalternas e combateria as mazelas humanas e a desigualdade social, tal como afirma o narrador: "[esses líderes messiânicos] eram a voz daquela melancolia e eram os amigos do pobre, os ásperos juízes do rico, os consoladores austeros" (QUEIRÓS, 2009, p. 123). Para Eliziel, Jesus teria essas qualidades, pois, para ele, "o Mestre pregava a fraternidade entre os homens, o perdão, a caridade, a humildade, a grandeza, a poderosa virtude do sacrifício" (QUEIRÓS, 2009, p. 129).

O povo, dessa forma, precisaria de um líder que prezasse por tais valores positivos e que os protegesse das classes mais elevadas. Jesus estaria próximo do povo, pois ele "[...] aceitava na sua companhia as mulheres transviadas, os publicanos, todos os pecadores" (QUEIRÓS, 2009, p. 131), ou seja, as camadas mais baixas e marginalizadas da sociedade. Portanto, para Eliziel, Jesus poderia ser 
um herói messiânico por prezar esses valores e por ser um representante das camadas desfavorecidas.

Destacamos que essa é a visão de Eliziel, um policial do Templo; logo, inferese que ele é um homem que não pertence às camadas mais elevadas, nem às mais baixas. Além disso, podemos dizer que os ideais de Eliziel representariam também os ideais do coletivo, uma vez que esse personagem almeja melhores condições para os subalternos, além de se identificar com os anseios populares, pois ele afirma que

estava profundamente ligado ao povo pela raça e pelo instinto [...] eu via, compreendia, sabia o povo. Infeliz, desprezado, eternamente escravo, esmagado pelo tributo da dominação e pelo dízimo, refugiava-se, maltratado da terra, na esperança dum libertador, dum Messias (QUEIRÓS, 2009, p. 123).

O personagem, dessa maneira, aponta que o povo estava infeliz, pois vivia sob a dominação das classes superiores. Novamente, estendemos essas críticas ao século XIX, pela aproximação da situação das camadas marginalizadas, que, nessa época, possuíam pouca ou nenhuma voz, já que a sociedade burguesa do Oitocentos, inserida no sistema capitalista de produção, não dá voz ao marginalizado.

Além disso, a classe dominante é descrita por Eliziel de forma negativa, tal como pode ser observado no episódio em que o narrador participa de uma ceia com vários membros dessa elite, tais como "membros do sanedrim, escribas, sacerdotes, herodianos, saduceus, fariseus. Todos eram zelosos devotos, amplos em sacrifícios [...]" (QUEIRÓS, 2009, p. 143). Sob o efeito do vinho, eles são vistos, pelo narrador, com características animalescas: "alguns, estendidos sobre leitos como animais que ruminavam, tinham as túnicas soltas, os braços nus" (QUEIRÓS, 2009, p. 143). Além de serem vistos como uma multidão que "bradava, uivava, cantava, rojava-se pelo chão. Era bestial e imundo" (QUEIRÓS, 2009, p. 148).

O narrador observa que os convidados apontam os erros dos outros, como pode ser visto na crítica do tenente romano Públio Sexto sobre os hábitos alimentares dos que vivem em Jerusalém; além disso, fala-se também sobre a diferença entre o comportamento das mulheres romanas do das que vivem na região de Jerusalém: "estas mulheres são castas e cuidadosas, as romanas são devassas [...] São os seus costumes que as tornam desejadas, que as fazem mais apetitosas 
que todas as farinhas molhadas em leite que elas põem na face [...]" (QUEIRÓS, 2009 , p. 145). Ouve-se também a história de adultérios de mulheres casadas. $O$ narrador também afirma que entre outros assuntos, "alguns gabavam-se de devassidões ocultas. Falavam de dinheiro, de banquetes, de mulheres, de prostituições sagradas no fundo dos bosques" (QUEIRÓS, 2009, p. 147), assuntos esses que parecem ser o foco de comentários na sociedade de Cristo; ou seja, os presentes criticam a devassidão alheia, mas eles mesmos são devassos, por estarem envolvidos em "devassidões ocultas", o que mostra a sua hipocrisia.

Destacamos a forma como a mulher adúltera é retratada, segundo essa elite. $\mathrm{O}$ adultério parece fazer parte do cotidiano do Império Romano, devido à quantidade de casos relatados e observados pelo narrador. Contudo, observa-se uma mudança de comportamento no modo de agir dessa elite: sob o efeito do vinho, o assunto do adultério parece adquirir certo ar de comicidade, como pode ser visto na passagem abaixo, em que Públio Sexto relata uma anedota do cotidiano romano:

- Lêntulo casa com uma virgem patrícia, neta de cônsules: nove meses depois prepara, segundo o costume, para o filho que vai nascer, o berço de tartaruga, coberto de estofos e de ramos de loureiro, e expõe-no às boas palavras dos que passam. Mas toda a nobreza da Via Ápia rompe em risadas. O filho de Lêntulo era a imagem viva do bufão Euríalo, e tinha, como ele, três verrugas no queixo.

A risada fazia o ar sonoro. Públio, de pé, mancado, com a túnica rota, descomposto, gritava:

- Ouvi, ouvi!

Escutavam com um riso inquieto. (QUEIRÓS, 2009, p. 147).

Entretanto, os mesmos que riem desse episódio contado por Públio Sexto são os que condenam moralmente o ato do adultério, o que mostra a sua hipocrisia, pois o riso demonstra que os presentes se identificam com esses comportamentos considerados imorais, evidenciado que eles já tiveram um relacionamento adúltero ou conhecem pessoas que já passaram por essa situação. Assim, a hipocrisia se dá pelo fato de recriminarem algo que eles próprios fazem.

A ceia é interrompida com a notícia da prisão da esposa de Jesus de Barrabás, presa por trair o marido. Nessa cena, tem-se a presença da elite:

[...] fariseus, escribas, sacerdotes, recuavam, escondiam a cabeça nos mantos, estendiam a mão espalmada, esconjurando: 
- Lapidada ${ }^{2}$, lapidada - disseram irritados.

Alguns cuspiam-lhe sobre o seio. E saíam apressados, erguendo os mantos, para que não tocassem o chão, impuro pelo contato da mulher adúltera (QUEIRÓS, 2009, p. 149).

Dessa forma, essa elite julga moralmente os atos alheios. A mulher adúltera, para eles, seria um exemplo de impureza; portanto, com esse olhar preconceituoso, a mulher precisaria de uma punição. Observa-se também nesse episódio, que o povo parece ter o mesmo pensamento que a classe dominante, ao pedir a lapidação da mulher: "o povo cruel dizia num clamor: - Lapidada, que seja lapidada! [...] Havia um clamor; o povo pedia a lapidação" (QUEIRÓS, 2009, p. 156-157). Além disso, percebe-se que esse evento mobilizou todas as esferas sociais:

A multidão dura clamava: todos corriam, curiosos; vinham as vendedoras de pombas, os cambiadores do oiro; os escribas saíam do santuário; vinham os pregões, os demandistas, os que passeiam na rua com fardos, ou conduzindo gados; os doentes da piscina arrastavam-se, os coxos corriam com grandes deslocações nas suas muletas (QUEIRÓS, 2009, p. 155).

Nesse caso, percebemos que o povo é descrito por Eliziel como distante da elite, uma vez que o narrador sugere que os pobres estariam infelizes porque não se viam representados pelos líderes, por estes se aterem a coisas distantes da vida real; isto é, "os saduceus afogados nos seus repousos, os fariseus perdidos nas suas devoções, os escribas e doutores absorvidos nas suas escolas, não viam o estado das almas. Além de tudo, estavam longe do povo, numa separação desdenhosa e enfática” (QUEIRÓS, 2009, p. 123). Vê-se que esses membros das camadas superiores vivem em um mundo à parte, longe do povo. Contudo, essa distância entre a elite e a população não parece ser observada no episódio da mulher adúltera, já que a massa apresenta o mesmo desejo que a classe dominante.

Sabendo, então, que tanto os mais desfavorecidos quanto os mais abastados almejavam pela condenação da mulher, seria esperado que Jesus também a condenasse, para ir ao encontro dos ideais da população, de forma a agradá-la. Porém, como ele protege os desamparados, ele discorda da opinião de que a mulher deva ser lapidada, contrariando o desejo do povo.

O personagem João, provavelmente o discípulo de Jesus na Bíblia, observando que o Cristo vai contra a voz geral, tenta fazer com que o Mestre siga a

\footnotetext{
${ }^{2}$ Segundo a definição de Houaiss; Villar (2009, p. 1156), nesse contexto, lapidar significa "atacar ou matar com pedras; infligir o suplício da lapidação a; apedrejar".
} 
vontade da maioria: "[...] João, exaltado, tomando o braço ao escriba, bradou-lhe poderoso, irritado: - Quem te disse que o Rabi de Nazaré perdoa a mulher adúltera? - Ele manda lapidá-la" (QUEIRÓS, 2009, p. 158). Contudo, Jesus afirma:

- Sim, lapidai-a, e aquele de vós outros que se julgar sem pecado, que the atire a primeira pedra!

A sua voz era forte, côncava, misteriosa, assustava.

A imensa multidão estava calada, absorta; alguns rumores elevaramse: os fariseus, os escribas afastavam-se, rosnando. (QUEIRÓS, 2009, p. 158).

Com isso, ao perdoar a mulher adúltera, Jesus também aponta a hipocrisia dessa sociedade que só sabe apontar os erros alheios. Em outras palavras, o narrador Eliziel afirma que: "alegrava-me em ver, com uma palavra simples e genial, a hipocrisia de uma raça ferida na sua essência" (QUEIRÓS, 2009, p. 158).

Ao evidenciar a hipocrisia como uma característica dessa sociedade, Eça também aborda questões referentes ao tempo dele, pois, tal como na época de Cristo, a hipocrisia está presente no Oitocentos, já que, nesse século, o adultério feminino ainda é visto como imoral e punido pela lei. É importante pontuar também que só seria punido o adultério cometido pela mulher.

Além disso, vê-se que, ao apontar a hipocrisia, o povo se assusta, pois, além de isso quebrar a expectativa das pessoas, já que elas almejavam pela lapidação, também serve para mostrar os seus defeitos: uma sociedade intolerante, contraditória e desunida, já que, como a mulher adúltera está numa condição marginalizada, o povo, por sua vez, deveria absolvê-la, mostrando, dessa forma, a união dos desfavorecidos.

Outra característica que aproxima a sociedade do tempo de Cristo à de Eça é a busca do lucro, pois Eliziel observa que essa prática - típica do capitalismo oitocentista - também está presente no tempo dele. Para ele, os cidadãos usariam o Templo, que era um lugar sagrado, para realizar atividades mercantis e consequentemente alcançarem o lucro:

Para qualquer lado que olhasse daquela organização sacerdotal, só via uma hipocrisia ou uma especulação, ou uma vaidade ou uma humilhação: os sacerdotes que se prostram à entrada do santuário, sustentado por dois levitas risonhos, no seu êxtase enfastiado; os argumentadores, vãos, artificiais, vazios; os doentes que cantam os salmos, mendigam, riem, fazem a ostentação ruidosa das suas chagas, tudo me dava um tédio obscuro e atormentado. Sentia em mim cóleras de bárbaro: agradava-me a ideia de desprezar com um 
açoite aquele sacerdócio aviltado que vive do Templo, the compreende a vaidade e lhe aceita o lucro. Quantas vezes eu percebi o sorriso imperceptível dos sacerdotes sacrificadores diante da piedade simples e crente de pobres galileus, e de provinciais ingénuos! (QUEIRÓS, 2009, p. 151).

O narrador reforça a hipocrisia da sociedade, desde a classe dominante (os sacerdotes), até à classe mais baixa (os mendigos). Para Eliziel, o Templo deveria ser um local sagrado, reservado à elevação espiritual. Contudo, o Templo se torna mundano, sua função deixa de ser religiosa e passa a ser comercial, pois é lá que o homem alcança o lucro, com a troca e venda de mercadorias.

Além do mais, em outras passagens, é abordada a importância do dinheiro nas relações humanas. Eliziel descreve Jesus como alguém que "vivia como um simples" (QUEIRÓS, 2009, p. 134), e era desapegado do dinheiro e de coisas materiais. Segundo o narrador, é com base nesses pressupostos que os "discípulos seguiam-no assim, enlevados naquelas ambições ideais, sem roupas, sem provisões, sem dinheiro" (QUEIRÓS, 2009, p. 134).

Sabendo que Eça foi um grande crítico de seu tempo, nota-se que o narrador Eliziel também o é, pois ele é um observador e questionador dos problemas que afligem a sua sociedade. Ele, por exemplo, interroga-se sobre as qualidades de sua cidade:

Que temos nós em Jerusalém de bom, de justo?

- Temos uma pátria? Não [...]

- Temos uma religião, uma fé? Não [...]

- Temos nós uma ciência, uma lei elevada, forte, justa? Não! (QUEIRÓS, 2009, p. 151).

Esse trecho lembra o folhetim "Lisboa", publicado no dia 13 de outubro de 1866, no jornal Gazeta de Portugal, também inserido na coletânea Prosas Bárbaras. O narrador desse relato também se questiona sobre as qualidades de sua cidade: "Lisboa que faz?" (QUEIRÓS, 2004, p. 129). Tal como Eliziel, esse narrador rebaixa a cidade: "Lisboa nem cria, nem inicia; vai [...] em religião, nem tem a devoção dos monges, nem a impiedade irónica [...] em política, copia Sancho Pança" (QUEIRÓS, 2004, p. 131).

Observa-se, portanto, nas duas descrições, que as ideologias dos dois sujeitos são semelhantes, pois ambos apresentam uma perspectiva negativa sobre suas cidades. Para eles, Jerusalém e Lisboa não seriam constituídas por grandes ideais, já que seriam lugares atrasados, fazendo-nos questionar se Jerusalém seria 
atrasada por estar longe da capital do Império Romano, e Portugal por ser uma semiperiferia do sistema capitalista ${ }^{3}$.

Como um crítico de seu tempo, Eliziel acredita que Jesus poderia melhorar a sociedade, isto é, fazer com que se crie um sentimento nacional, pois, nas palavras dele, "a ideia duma pátria perseguia-me, como uma voz que pede socorro" (QUEIRÓS, 2009, p. 152). Para ele, Jesus "é o único homem, que nos poderia salvar, ou como um Messias, ou como um Macabeu, ou como um simples, que tem a fé e a justiça! Mas terá ele a ação?" (QUEIRÓS, 2009, p. 152). Com esse pensamento, Eliziel atribui a esperança ao Cristo, porém, questiona-se se ele seria capaz de agir. O poder da ação, portanto, seria fundamental para um líder revolucionário.

Contudo, como já apontado acima, no final da narrativa, no diálogo entre Jesus e Eliziel, o primeiro se abstém de iniciar uma revolução, uma vez que ele parece estar mais preocupado com as questões espirituais do que com as terrenas. Dessa forma, Jesus não teria a ação necessária a um líder revolucionário. As palavras e ensinamentos do Cristo, portanto, não seriam suficientes para atingir a melhora da nação, pois, para Eliziel, seria necessária uma ação prática.

Esse posicionamento do narrador, cuja expectativa é a atitude revolucionária ativa de Jesus, permite-nos refletir sobre o Portugal oitocentista. A afirmação de Bueno, destacada no início do trabalho, na qual a autora discorre que os questionamentos de Eliziel a Cristo também seriam os questionamentos esperados dos membros da geração de Eça, é um reflexo da decadência econômica e cultural que Portugal passa ao longo do século XIX. Isto é, assim como na Jerusalém de Jesus, também seria preciso uma atitude revolucionária para o país ibérico.

Assim, se Eliziel afirma que, no tempo de Cristo, "a esperança do Messias era ativa" (QUEIRÓS, 2009, p. 124) e, dessa forma, Jesus seria considerado por ele como um possível líder revolucionário, poderíamos fazer uma analogia com o século XIX. O Portugal do Oitocentos, desta forma, também precisaria de um líder e de uma mudança que viesse a melhorar a situação do país.

Saraiva (1982, p.117), ao analisar os romances posteriores à publicação dessa narrativa, tais como $O$ primo Basílio e Os Maias, afirma que Eça faz uma espécie de inquérito da vida social portuguesa. Um dos pontos elencados pelo

\footnotetext{
${ }^{3}$ Boaventura de Sousa Santos defende Portugal como um país semiperiférico. Para ele, "Portugal era o centro em relação às suas colônias e a periferia em relação à Inglaterra" (SANTOS, 1994, p. 58). 
estudioso diz respeito à incapacidade da classe dirigente. Para o crítico, essa elite teria "uma mentalidade burguesa considerada isoladamente do conjunto de que faz parte" (SARAIVA, 1982, p. 134). Porém, como já relatamos em nossa análise do episódio da mulher adúltera, a mentalidade das classes desfavorecidas seria semelhante à das classes dominantes.

Contudo, mesmo que haja semelhança de mentalidade entre o povo e a elite, é possivel traçar alguns paralelos entre a afirmação de Saraiva em relação a esses romances e a narrativa "A morte de Jesus". Apesar de termos visto que o narrador Eliziel afirma que a elite estava "longe do povo, numa separação desdenhosa e enfática" (QUEIRÓS, 2009, p. 123), também observamos que o povo apresenta ideais semelhantes aos da classe dominante, como é o caso do episódio da mulher adúltera referido, o que nos leva a crer que o problema da nação não estaria apenas na incapacidade dos dirigentes, mas também no modo de pensar do povo. Além do mais, Saraiva (1982) critica a postura de Eça, por este supostamente não notar, em seus romances, que

a incapacidade da burguesia dirigente provém precisamente de que a massa sobre que ela assenta tem um baixo nível social e cultural e uma consciência muito incipiente do seu papel e da sua verdadeira força; que precisamente a burguesia especulava com isso e the interessava manter a massa naquele baixo nível; [...] que o problema consistia precisamente em alargar e tornar mais consciente a intervenção da massa na vida política e cultural do país; [...] que o problema e a sua chave não estavam na mentalidade da elite, mas na massa populacional de que essa elite é uma segregação (SARAIVA, 1982, p. 137-138).

Entretanto, ao contrário do que Saraiva afirma, cremos que o final do conto apresenta um olhar reflexivo sobre a massa popular, pois Eliziel percebe que Jesus não fará uma revolução, já que, como mostramos anteriormente, ele afirma "Vai-te: o meu reino não é deste mundo" (QUEIRÓS, 2009, p. 165). Sendo assim, caberia ao povo realizar a mudança da sociedade. Se, por um lado, o povo partilha os mesmos ideais que a elite, essa atitude poderia ser fruto do desconhecimento da consciência de sua força alcançada pela união entre os mais desfavorecidos.

O final da narrativa, que mostra uma descrença nas lideranças, a partir da percepção de que Jesus não faria a revolução, para nós, mostraria que a revolução deveria começar pelo povo. Trata-se, portanto, da defesa de uma mudança de 
pensamento. A massa popular, dessa forma, precisaria ter a noção de sua união, pois é só ela quem poderia mudar a nação.

Saraiva (1982) defende que a obra literária deve enaltecer as aspirações da sua época. Nas palavras do crítico, a arte deve

estar ao alcance e dentro dos interesses do homem comum; procurar melhorar esse homem comum; proceder pela observação e pelo estudo dos fatos sociais observáveis; estar de acordo com o ideal revolucionário. O que tudo se resume na ideia de que a arte não é um fim em si própria, mas está a serviço da coletividade (SARAIVA, 1982, p. 112).

Sabendo que a arte deve estar a serviço da coletividade, nota-se a preocupação de Eça com os assuntos sociais, já que ele faz uma crítica, através do olhar crucial do personagem Eliziel, sobre a sociedade da época de Jesus e do século XIX, em que revela a hipocrisia da classe dominante, mostra que o povo precisa de um líder e que uma revolução/mudança é necessária. Porém, Eliziel tem as suas expectativas quebradas ao constatar que Jesus não é um líder revolucionário.

Além do mais, como uma tentativa de aproximar a crítica identificada na narrativa ao contexto de produção da obra, podem nos ser úteis as ponderações de Menezes, que afirma que Eça emerge "num país atrasado, estacionado nos limites de um capitalismo incipiente, rudimentarmente industrial” (MENEZES, 1962, p. 63). Assim, com esse contexto marcado por um sentimento de desânimo em relação a Portugal, podemos deduzir que Eça, no início da carreira, além de trazer um olhar sobre uma narrativa bíblica, reflete sobre a situação de seu país. Álvaro Manuel Machado afirma que "a Geração de 70 [da qual Eça fez parte] representa, em Portugal, uma profunda revolução cultural" (MACHADO, 1986 p. 12).

Eça, portanto, no final da narrativa, evidencia a desilusão na crença de que um líder revolucionário irá salvar o povo. Além disso, esse fato sugere que a mudança não deve partir dos dirigentes, mas da massa popular. Da mesma forma, a decepção de Eliziel frente à incapacidade de Jesus iniciar uma revolução pode se relacionar à desilusão da geração de Eça, já que, nos dois contextos, há a sugestão de que o país não deveria esperar por um líder messiânico ${ }^{4}$.

\footnotetext{
${ }^{4}$ Deste modo, o texto de Eça poderia ser considerado como antimessiânico. José Van Der Besselaar (1982, p. 10) considera o sebastianismo com uma espécie de messianismo. Ainda segundo o autor, o messianismo designaria a "cega fé das massas populares num líder político, julgado capaz de acabar 
Vimos, portanto, que Jesus é representado, segundo as descrições de Eliziel, com características físicas detalhadas e sentimentos contraditórios (amor ao próximo, compaixão e piedade, em contraste com a cólera, por exemplo), fato que o faria se aproximar de um sujeito comum. Além disso, essa seria uma visão canônica da vida de Jesus, porém contada sob a perspectiva de um personagem ficcional bíblico, que traz uma crítica a Jesus, pelo fato de ele não querer iniciar uma revolução.

Em sua conhecida carta ao Conde de Ficalho, escrita em Londres, datada de 15 de junho de 1885, Eça diz:

À sua carta recebida em Bristol, respondo de Londres, onde vim indagar sobre pedras, nomes de ruas, mobílias e toilettes para a minha Jerusalém. Digo minha - e não de Jesus, como pedia a devoção, ou de Tibério, como pedia a história, - porque ela realmente me pertence, sendo, apesar de todos os estudos, obra da minha imaginação. Debalde, amigo, se consultam in-fólios, mármores de museus, estampas, e coisas em línguas mortas: a história será sempre uma grande fantasia. [...] Reconstruir é sempre inventar. [...] Além disso, 0 isolamento lança-me na leitura, que me lança na erudição: e reaparece então o latente e culpado apetite do romance histórico (QUEIRÓS, 1986, p. 551).

Essa carta escrita aproximadamente 15 anos depois de "A morte de Jesus" nos mostra que Eça ainda se interessava por narrativas que se passassem em Jerusalém (dois anos depois ele publicaria $A$ relíquia). Percebe-se a preocupação do autor de Prosas Bárbaras em estudar a fundo o período histórico destacado na narrativa para fazer uma recriação das tradições. No entanto, nessa carta, Eça ressalta que "reconstruir é sempre inventar"; assim, a literatura seria invenção, não a reprodução do ocorrido. Deste modo, a recuperação do passado não deve ser pautada pela representação fiel do cotidiano da época retratada, uma vez que está explícito que Eça estaria interessado em uma Jerusalém particular, ao se referir a

com os abusos existentes e de inaugurar uma nova era de bem-estar geral". Essa definição parece se encaixar das atribuições que seriam destinadas a Jesus. Besselaar relata que esse mito estaria fortemente relacionado à História de Portugal, contudo, o estudioso destaca que ele perde forças em meados do século XIX, já que o destino de Portugal deixa de ser explicado de modo folclórico e passa a ser questionado de modo racional. Para Besselaar: "O sebastianismo morreu, não porque alguém tivesse dado a prova cabal de que D. Sebastião morreu, mas porque a crença na sua vinda já não se compadecia com o conjunto das condições sociais e culturais que se foram introduzindo na sociedade portuguesa depois da Revolução de 1820. Tornava-se um assunto cada vez mais folclórico. Portugal passou a interpretar o seu destino histórico à luz de ideologias mais racionais, tais como o liberalismo, o socialismo, a democracia, etc., - ideologias igualmente não destituídas de elementos míticos, mas geralmente bem disfarçados sob estruturas racionais" (BESSELAAR, 1987, p. 161). 
"minha Jerusalém". Segundo o escritor, para recriar o passado não bastaria fazer uma pesquisa histórica, pois a obra literária é fruto da imaginação do autor. Dessa forma, Eça recria-o para dialogar com o texto bíblico, amplamente conhecido, mas, sob um ponto de vista diferente.

Deste modo, a narrativa "A morte de Jesus", publicada no início da carreira de Eça, apresenta algumas características inovadoras. Apesar de utilizar alguns recursos comuns dos romances históricos, como a tópica do manuscrito encontrado, esse relato apresenta um narrador em primeira pessoa cujo olhar crítico faz aproximar a sociedade do tempo de Cristo ao de Eça.

\section{Referências}

BESSELAAR, José Van Den. O Sebastianismo: história sumária. Lisboa: Ministério da Educação e Cultura, 1987.

BUENO, Aparecida de Fátima. As imagens de Cristo na obra de Eça de Queiroz. 2000. 233f. Tese (Doutorado em Letras) - Instituto de Estudos da Linguagem, Universidade Estadual de Campinas. Campinas, 2000.

HOUAISS, Antônio; VILLAR, Mauro de Salles. Dicionário Houaiss da língua portuguesa. Rio de Janeiro: Objetiva, 2009.

MACHADO, Álvaro Manuel. A geração de 70 - uma revolução cultural e literária. Lisboa: Instituto de Cultura e Língua Portuguesa, 1986.

MARINHO. Maria de Fátima. A intromissão da História na ficção de Eça de Queirós. In: BERRINI, Beatriz (org). Eça \& Machado. Conferências e textos das mesas redondas do Simpósio Internacional Eça \& Machado. São Paulo: EDUC; Fapesp; Fundação Gulbnian, 2005, p. 169-183.

MENEZES, Djacir. Crítica social de Eça de Queiroz. 2. ed. Fortaleza: Imprensa Universitária do Ceará, 1962.

NERY, Antonio Augusto. Santidade e humanidade: aspectos da temática religiosa em obras de Eça de Queirós. 2005. 209f. Dissertação (Mestrado em Letras) Universidade Federal do Paraná, Curitiba, 2005.

PIWNIK, Marie-Hélène. Introdução. In: QUEIRÓS, Eça de. Contos I. Lisboa: Imprensa Nacional-Casa da Moeda, 2009. p. 15-32.

QUEIRÓS, Eça de. Obras de Eça de Queirós. v. 3. Porto: Lello \& Irmão, 1986.

Textos de Imprensa I (da Gazeta de Portugal). Lisboa: Imprensa NacionalCasa da Moeda, 2004. 
$\mathbb{B}_{\text {ปisisi }} \mathcal{A}$

Contos I. Lisboa: Imprensa Nacional-Casa da Moeda, 2009.

REIS, Jaime Batalha. Introdução. Na primeira fase da vida literária de Eça de Queirós. In: QUEIRÓS, Eça de. Prosas Bárbaras. Porto: Lello \& Irmão, 1951. p. 553.

SANTOS, Boaventura Sousa. Pela Mão de Alice: o social e o político na pósmodernidade. 7. ed. Porto: Edições Afrontamento, 1994.

SARAIVA, António José. As ideias de Eça de Queirós. 2. ed. Lisboa: Bertrand, 1982.

Recebido em 11/01/2018

Aceito em 12/03/2018

Publicado em 03/04/2018 